\title{
Katarzyna Samek
}

\section{DZIAŁANIA REKRUTACYJNE FIRM W MEDIACH SPOŁECZNOŚCIOWYCH NA PRZYKŁADZIE PRZEDSIĘBIORSTW MŚP Z WOJEWÓDZTWA KUJAWSKO-POMORSKIEGO}

\begin{abstract}
Zarys treści: Media społecznościowe w ostatnim czasie odgrywają coraz większą rolę w działaniach marketingowych i rekrutacyjnych wielu firm. Umożliwiają one bowiem dostęp nie tylko do pożądanej grupy klientów, ale także do potencjalnych pracowników. Pozwala to przenieść do mediów społecznościowych część działań rekrutacyjnych, które dotąd firma wykonywała w strukturach własnej organizacji, stąd celem artykułu była identyfikacja rodzajów i przykładów mediów społecznościowych oraz działań rekrutacyjnych w nich podejmowanych przez małe i średnie przedsiębiorstwa z województwa kujawsko-pomorskiego.
\end{abstract}

Słowa kluczowe: media społecznościowe, rekrutacja pracowników

K 1 a s y fi k a c j a JEL: J24; L21; M15

\section{WSTĘP}

W ciągu ostatnich kilku lat media społecznościowe stały się bardzo popularne, niemal codziennie pojawiają się $\mathrm{w}$ prasie, $\mathrm{w}$ telewizji, $\mathrm{w}$ radio i w codziennych rozmowach. Dzieje się tak, ponieważ użytkownicy Internetu, w tym mediów społecznościowych zainteresowani są już nie tylko światem wirtualnym, ale i także światem korporacyjnym. W środowisku internetowym firmy dążą do budowania relacji z klientami, do przyciągnięcia ich uwagi wśród setek informacji i publikowanych komunikatów przez konkurentów. Zaangażowanie klientów w mediach społecznościowych dla wszystkich przedsiębiorstw nie jest proste do osiągnięcia. Coraz więcej firm ma problem ze skuteczną

\footnotetext{
* Adres do korespondencji: Katarzyna Samek, Uniwersytet Mikołaja Kopernika w Toruniu, Wydział Nauk Ekonomicznych i Zarządzania, Katedra Logistyki, ul. Gagarina 13a, 87-100 Toruń, e-mail: kasia.samek@gmail.com.
} 
komunikacją w mediach społecznościowych, nie wiedząc jak skutecznie wykorzystać opinie i pomysły klientów umieszczane w tych mediach. Ponadto funkcjonowanie współczesnych przedsiębiorstw w burzliwym i zmiennym otoczeniu rynkowym, w którym konsumenci coraz częściej wymagają komunikacji online jest wyzwaniem dla wielu z nich. Problemem stają się również odpowiednie działania rekrutacyjne firm określane jako „zespół celowych, skoordynowanych działań, które związane są obsadzaniem stanowisk organizacyjnych osobami mającymi pożądane kwalifikacje zawodowe i psychiczne" [Król, Ludwiczyński, 2006, s.197].

Znalezienie odpowiedniej kadry pracowniczej jest problemem wielu współczesnych przedsiębiorstw. W 2014 roku z problemem tym borykało się 35\% przedsiębiorstw na świecie i 32\% firm działających na rynku polskim [ManpowerGroup, 2013]. Tradycyjne działania rekrutacyjne, oparte na umieszczeniu oferty pracy na stronie internetowej firmy już nie wystarczą. Konieczne jest aktywne działanie firmy w mediach społecznościowych, szczególnie tych, które służą celom rekrutacyjnym, jak np. serwis społecznościowy LinkedIn, Pracuj.pl czy Golden Line i stała komunikacja z użytkownikami tych serwisów. Współczesne przedsiębiorstwa powinny otworzyć na nowe sposoby komunikacji z potencjalnymi pracownikami, wykorzystując w tym celu media społecznościowe. Podkreśla to Listwan twierdząc, że organizacje powinny stosować taki „sposób komunikowania się organizacji z rynkiem, aby zdobyć odpowiednią grupę kandydatów na wakujące stanowiska" [Listwan, 2010, s. 115].

Szybkie tempo rozwoju mediów społecznościowych i ich rosnąca popularność wśród użytkowników sprawiły, że są one szansą na pozyskanie nowych pracowników dla tych przedsiębiorstw, które potrafią sprostać współczesnym wymogom rynku pracy. Firmy bowiem muszą zdawać sobie sprawę z tego, że społeczności internetowe nie są już tylko biernymi uczestnikami Internetu. Coraz częściej użytkownicy mediów społecznościowych kreują w nich nie tylko swój wizerunek jako profesjonalistów w danej dziedzinie. Nawiązując trwałe relacje z podmiotami gospodarczymi kształtują także wizerunek firm i wpływają na ich pozycję konkurencyjną.

Obecnie, osoby, które szukają pracy korzystają z kilku rodzajów mediów społecznościowych, na których umieszczają swoje CV. Tradycyjny mechanizm szukania pracy został zastąpiony przez kryteria wyszukiwania ofert pracy w mediach społecznościowych. Dziś to pracodawcy szukają pracowników, a nie odwrotnie, stąd tak ważna jest komunikacja firm w mediach społecznościowych. Pracodawcy zaczynają dostrzegać możliwości mediów społecznościowych i ich skuteczność w zakresie komunikacji z klientami i prowadzenia rekrutacji. Selekcja pracowników coraz częściej odbywa się online, na podstawie profili zawodowych w mediach społecznościowych, bądź internetowych rozmów rekrutacyjnych. 
Współczesne przedsiębiorstwa, które dążą do miana atrakcyjnego pracodawcy powinny znać możliwości mediów społecznościowych i wykorzystywać szanse jakie niesie za sobą Internet. Sukces firmy coraz częściej podyktowany jest bowiem jej zdolnością do szybkiego reagowania nie tylko na zmiany rynkowe, ale także umiejętnością kreowania pozytywnego wizerunku „w sieci”. Znaczenie Internetu dla współczesnych organizacji podkreśla Nalazek, twierdząc, iż: „Internet zmienia gospodarkę jak burza, porównywalna tylko z rewolucją przemysłową. Ci, którzy jej zwiastuny dostrzegli odpowiednio wcześnie, już dzisiaj zbierają owoce wprowadzonych zmian. Ślepi na zmiany odpadną" [Nalazek 1999, s. 14].

Celem artykułu jest opisanie podstawowych zagadnień związanych z mediami społecznościowymi i prezentacja wyników badania na temat ich wykorzystania w rekrutacji pracowników przez przedsiębiorstwa z województwa kujawsko-pomorskiego.

\section{POJĘCIE MEDIÓW SPOŁECZNOŚCIOWYCH}

Pojęcie mediów społecznościowych (ang. social media) w Polsce pojawiło się stosunkowo niedawno - kilka lat temu, stąd niewiele jest opracowań naukowych podejmujących problematykę ich wykorzystania w biznesie. Problemowym jest jednak samo zdefiniowanie tego pojęcia. Stały rozwój mediów społecznościowych skutkuje tym, że ich definicja ulega ciągłym modyfikacjom.

W literaturze występuje kilka definicji mediów społecznościowych. Gogołek z kolei media społeczne utożsamia z nową formą aktywności w Internecie, która opiera się na grupach społecznościowych [Gogołek, 2010, s.160]. Mount i Martinez media społecznościowe określają jako zestaw narzędzi online, które są dostępne dla publicznych użytkowników oraz ,wspierają wymianę idei, tworzenie i edytowanie treści poprzez wzajemną interakcję i współpracę użytkowników" [Mount, Martinez, 2014, s. 126]. Inne podejście do prezentują Kaplan i Haenlein. Określają oni media społecznościowe jako, ,grupę bazujących na internetowych rozwiązaniach aplikacji, które opierają się na ideologicznych i technologicznych podstawach Web 2.0, i które to umożliwiają tworzenie i wymianę wygenerowanych przez użytkowników treści" [Kaplan, Haenlein 2010, s. 59]. Z kolei Drab-Kurowska, definiując media społecznościowe jako „kanały komunikacyjne umożliwiające interakcję pomiędzy internautami za pomocą takich technologii, jak fora, grupy dyskusyjne, blogi, komunikatory, e-maile, dzielenie się muzyką itp.” [Drab-Kurowska 2012, s. 179].

Naukowcy, jak i przedstawiciele firm maja problem nie tylko z właściwym określeniem pojęcia mediów społecznościowych, ale także z ich właściwym sklasyfikowaniem. Okazuje się bowiem, że wiele z nich bazuje na kilku poziomach społecznych interakcji, stąd powinno się je zaliczyć nie do jednej, ale do 
kilku kategorii [Kaznowski, 2010a]. Chociażby YouTube, który wykorzystywany jest jako narzędzie do informowania, ale także dostarczania rozrywki.

Tabela 1. Klasyfikacja mediów społecznościowych ze względu na ich cele zastosowania w biznesie

\begin{tabular}{|c|c|c|}
\hline $\begin{array}{l}\text { RODZAJ MEDIÓW } \\
\text { SPOLECZNOŚCIO- } \\
\text { WYCH }\end{array}$ & $\begin{array}{l}\text { CELE ZASTOSOWANIA } \\
\text { W BIZNESIE }\end{array}$ & $\begin{array}{l}\text { PRZYKŁAD MEDIÓW SPOŁECZNO- } \\
\text { ŚCIOWYCH }\end{array}$ \\
\hline \multicolumn{3}{|c|}{ Budowanie i podtrzymanie relacji } \\
\hline $\begin{array}{l}\text { Serwis społecznościo- } \\
\text { wy (towarzyski) }\end{array}$ & $\begin{array}{c}\text { Budowanie wizerunku, angażowanie } \\
\text { klientów, przekazywania i pozyskiwa- } \\
\text { nie informacji }\end{array}$ & Facebook, Google + \\
\hline $\begin{array}{l}\text { Serwis społecznościo- } \\
\text { wy dla osób aktywnych } \\
\text { zawodowo (biznesowy) }\end{array}$ & $\begin{array}{c}\text { Rekrutacja pracowników, budowanie } \\
\text { wizerunku firmy, nawiązywanie kon- } \\
\text { taktów biznesowych }\end{array}$ & Linkedln, Golden Line \\
\hline \multicolumn{3}{|c|}{ Współdzielenie } \\
\hline Serwis wideo & $\begin{array}{c}\text { Budowanie wizerunku, dotarcie do } \\
\text { nowych klientów, prezentacja pro- } \\
\text { duktów }\end{array}$ & YouTube, Dailymotion \\
\hline Serwis foto & $\begin{array}{l}\text { Budowanie wizerunku, prezentacja } \\
\text { firmy i produktów }\end{array}$ & Pinterest, Instagram, Snapchat \\
\hline \multicolumn{3}{|c|}{ Bieżące informowanie i odnoszenie się do aktualności } \\
\hline Mikroblog & $\begin{array}{l}\text { Budowanie wizerunku, funkcja infor- } \\
\text { macyjna, budowanie relacji z klienta- } \\
\text { mi, angażowanie klientów }\end{array}$ & Twitter, Blip \\
\hline \multicolumn{3}{|c|}{ Publikacja treści (prezentacja opinii i poglądów) } \\
\hline Blog & $\begin{array}{l}\text { Kształtowanie wizerunku, funkcja } \\
\text { informacyjna }\end{array}$ & Blog firmowy \\
\hline Wiki & Budowanie firmowej bazy wiedzy & $\begin{array}{c}\text { Wikipedia, myfiles (encyklopedia } \\
\text { zarządzania) }\end{array}$ \\
\hline \multicolumn{3}{|c|}{ Sprzedaż produktów } \\
\hline Zakupy grupowe & $\begin{array}{c}\text { Zwiększenie sprzedaży, popularyza- } \\
\text { cja marki }\end{array}$ & Grupon, Gruper \\
\hline \multicolumn{3}{|c|}{ Współtworzenie i kooperacja } \\
\hline $\begin{array}{l}\text { Serwis crowdsourcin- } \\
\text { gowy }\end{array}$ & $\begin{array}{l}\text { Zdobywanie wiedzy i nowych pomy- } \\
\text { słów, badania i rozwój }\end{array}$ & Bank Pomysłów \\
\hline
\end{tabular}

Źródło: opracowanie własne na podstawie Kaznowski D., Podział i klasyfikacja mediów społecznych, witryna internetowa: http://networkeddigital.com/2010/05/10/podzial-i-klasyfikacjasocial-media, [data wglądu: 15.01.2017]. 
Próbą rozwiązania tego dylematu jest klasyfikacja autorstwa Kaznowskiego, który podzielił media społecznościowe ze względu na cele ich zastosowania w biznesie [Kaznowski, 2010a], wśród których wymienia: budowanie i podtrzymanie relacji, współdzielenie, bieżące informowanie i odnoszenie się do aktualności, publikacja treści, sprzedaż produktów, współtworzenie i kooperacja. W oparciu o to Kaznowski wyróżnił takie rodzaje mediów społecznościowych jak, serwis społecznościowy towarzyski i serwis społecznościowy biznesowy, serwis wideo i serwis foto, mikroblog, blog, wiki, zakupy grupowe oraz serwis crowdsourcingowy (tabela 1).

Zacierające się różnice pomiędzy różnymi rodzajami mediów społecznościowych powodują iż dokładne określenie ich ram jest stosunkowo trudne. Ważnym jest jednak fakt, ze media społecznościowe to nie tylko serwisy społecznościowe. Większość naukowców lokuje w nich także zbiorowości skupione wokół treści oraz różnego typu fora internetowe i blogi.

Różne definicje pojęcia mediów społecznościowych pociągają za sobą różne ich klasyfikacje, stąd klasyfikacja Kaznowskiego nie jest jedyną prezentowaną w literaturze. Jedną z ciekawszych i często cytowanych jest klasyfikacja mediów społecznościowych zaproponowana przez Kaplana i Heanleina (tabela 2).

Tabela 2. Klasyfikacja social media autorstwa Kaplana i Haenleina

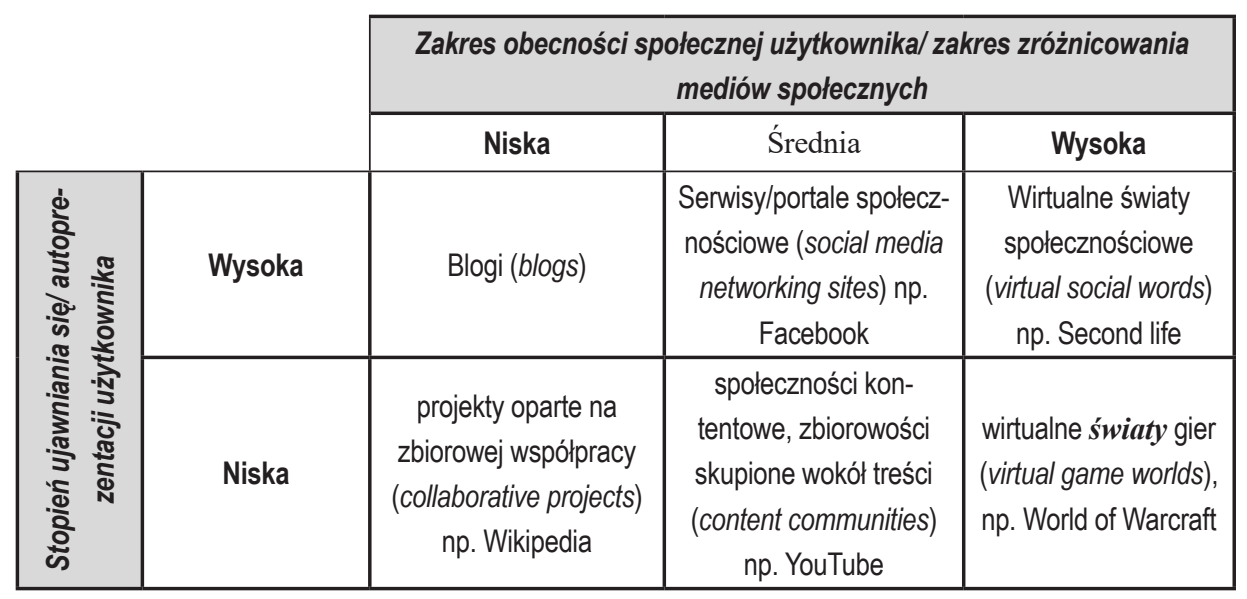

Źródło: Kaplan A., Haenlein M., 2010, Users of the world, unite! The challenges and opportunities of Social Media, Business Horizons, Vol. 53, Issue 1., ss. 59-68.

Jako kryterium podziału przyjęli oni:

- zakres obecności społecznej użytkownika, którą umożliwia dany rodzaj mediów społecznościowych (social presence), rozumiany jako wizualny lub dźwiękowy kontakt pomiędzy uczestnikami interakcji; 
- zakres zróżnicowania danego rodzaju mediów społecznościowych, którą użytkownik używa (media richness), czyli ilość informacji, rodzaj sygnałów, jaką jest w stanie przekazać dany rodzaj mediów do uczestników nawiązanej interakcji;

- $\quad$ stopień ujawniania się i autoprezentacji użytkownika w danym rodzaju mediów społecznościowych (self-disclosure $i$ self-presentation), czyli świadome lub nieświadome publikowanie osobistych informacji.

W oparciu o to Kaplan i Heanlein wyróżnili takie rodzaje mediów społecznościowych jak blogi, serwisy/portale społecznościowe, wirtualne światy społecznościowe, projekty oparte na zbiorowej współpracy, społeczności kontentowe, wirtualne światy gier. Z kolei Mazurek do mediów społecznościowych zalicza platformy społecznościowe, platformy komunikacyjne, internetowe repozytoria multimedialne, blogi i mikroblogi [Mazurek, 2010, ss.100-101].

Ciągła modyfikacja definicji i klasyfikacji mediów społecznościowych wynika z ich rosnącej popularności i tempa rozwoju w gospodarce. Współczesne firmy korzystają z kilku rodzajów mediów społecznościowych, a pojawiające się ich nowe możliwości i funkcje powodują, że powoli zacierają się różnice pomiędzy nimi. Coraz częściej bowiem jedno narzędzie mieści w sobie kilka funkcji i zastosowań w biznesie. Współczesne przedsiębiorstwa stoją przed ogromnym wyzwaniem jakim jest dobór właściwych rodzajów mediów społecznościowych $\mathrm{i}$ ich odpowiednie wykorzystanie w rekrutacji pracowników.

\section{MEDIA SPOŁECZNOŚCIOWE W DZIAŁANIACH PRZEDSIĘBIORSTW}

Obserwując doświadczenia zagranicznych firm, jak również rosnącą popularność mediów społecznościowych, polskie firmy zaczynają dostrzegać korzyści ekonomiczne i społeczne ich wykorzystania. W tabeli 3 przedstawiono podstawowe wartości ekonomiczne wykorzystania mediów społecznościowych z podziałem na sektory gospodarki.

Media społecznościowe postrzegane są przede wszystkim jako narzędzie firmy do komunikacji z otoczeniem. Wykorzystywane w działaniach marketingowych mają budować wizerunek firmy, sprzedawać i promować produkty. Firmy coraz częściej dostrzegają w nich także potencjał do budowania lojalnych społeczności, które umożliwiają pozyskanie wiernych klientów i wartościowych pracowników.

Interesujące podejście do wykorzystania mediów społecznościowych przez polskie firmy prezentuje A. Miotk. Autorka podzieliła polskich pracodawców na dwie grupy- „Tylko słucham” i „Słucham i działam” [Miotk, 2013, s.63]. Do pierwszej grupy „Tylko słucham” zaliczane są te firmy, które nie prowadzą aktywnych działań wizerunkowych w Internecie, a jedynie monitorują 
opinie o sobie i o konkurentach. Rzadko wchodzą w interakcje z użytkownikami mediów społecznościowych. Odmienna sytuacja odnosi się do pracodawców z grupy „Słucham i działam”. Posiadają oni kompleksową strategię komunikacji w mediach społecznych, jak również aktywnie uczestniczą w życiu społeczności internetowych. Z kolei opinie i pomysły użytkowników wykorzystują do rozwoju, poprawy oferowanych produktów [Jakrzewski, 2006, s. 34].

Funkcjonowanie przedsiębiorstw we współczesnej gospodarce cechuje się trendami społeczności internetowych. Obecni klienci czy potencjalni pracownicy poprzez media społecznościowe chcą mieć stały i szybki kontakt z organizacją, a opinie w Internecie rzutują na postrzeganie firmy w otoczeniu rynkowym. Stanowi to ogromne wyzwanie nie tylko dla specjalistów ds. marketingu, ale i specjalistów HR.

Polskie przedsiębiorstwa co prawda dopiero zaczynają poznawać możliwości mediów społecznościowych w rekrutacji, jednak postęp technologii i wymagania społeczne wymuszają ich stosowanie. Podkreśla to Igoe twierdząc, że obecne, młode pokolenie, które dopiero wchodzi na rynek pracy poprzez codzienne korzystanie z mediów społecznościowych może w znaczącym stopniu „wymusić" wykorzystanie tych mediów w firmach [Igoe, 2008, s. 31]. Zatem firmy coraz częściej podejmują działania z obszaru rekrutacji w mediach społecznościowych. Szczegółowy ich opis przedstawiono w tabeli 4.

Tabela 4. Działania firm w mediach społecznościowych w obszarze rekrutacji

\begin{tabular}{|l|l|}
\hline \multicolumn{1}{|c|}{ Działanie } & \multicolumn{1}{c|}{ Opis } \\
\hline $\begin{array}{l}\text { Przekazywanie infor- } \\
\text { macji o wolnych stano- } \\
\text { wiskach }\end{array}$ & $\begin{array}{l}\text { Dostęp do specjalistów, odpowiednie targetowanie oferty pracy, rozsyłanie } \\
\text { oferty poprzez sieci społeczne specjalistyczne oraz poprzez marketing wiru- } \\
\text { sowy }\end{array}$ \\
\hline Feedback informacyjny & $\begin{array}{l}\text { Pozyskanie informacji zwrotnej na temat oferty - informacje dotyczą zarówno } \\
\text { form bezpośrednich (aplikowanie specjalistów na dane stanowisko), jak i form } \\
\text { pośrednich (informacje na temat oferty od społeczności) }\end{array}$ \\
\hline $\begin{array}{l}\text { Dostęp do informacji o o } \\
\text { potencjalnych pracow- } \\
\text { nikach }\end{array}$ & $\begin{array}{l}\text { Pozyskanie informacji bezpośrednio z konta potencjalnych pracowników, gdzie } \\
\text { często użytkownicy umieszczaja pełne CV oraz informacje nieformalne zwią- } \\
\text { zane z praca, jaką obecnie wykonuja }\end{array}$ \\
\hline
\end{tabular}

Źródło: Dejnaka A. (2012), Nowe obszary zarzadzania zasobami ludzkimi. Pracownik i pracodawca w przestrzeni wirtualnej, „Zeszyty Naukowe Wyższej Szkoły Bankowej we Wrocławiu”, nr 30, s. 45 .

Media społecznościowe to nie tylko skuteczne narzędzie marketingowe, ale także rekrutacyjne. Współczesne przedsiębiorstwa zyskały nową możliwość przeprowadzania rozmów rekrutacyjnych i selekcji pracowników za pomocą dostępnych rozwiązań internetowych. W mediach społecznościowych mogą wyszukiwać pracowników o takich kwalifikacjach, które są dla nich odpowiednie, a tym samym obniżać koszty działań rekrutacyjnych 
Profile przedsiębiorstw w mediach społecznościowych to także nowa szansa na zbudowanie wizerunku firmy i relacji z potencjalnymi pracownikami. Nowe sposoby rekrutacji oparte na narzędziach internetowych to przede wszystkim postrzeganie firmy jako nowoczesnej dla młodego pokolenia. Firma, która dąży do miana innowacyjnej powinna aktywnie uczestniczyć w życiu społeczności internetowych i wykorzystywać możliwości mediów społecznościowych w rekrutacji pracowników.

\section{WYNIKI BADANIA WYKORZYSTANIA MEDIÓW SPOŁECZNYCH W DZIAŁANIACH REKRUTACYJNYCH PRZEDSIĘBIORSTW MŚP Z WOJEWÓDZTWA KUJAWSKO-POMORSKIEGO}

Badanie działań rekrutacyjnych firm w mediach społecznościowych na przykładzie przedsiębiorstw MŚP z województwa kujawsko-pomorskiego miało charakter pilotażowy dla zagadnień metodycznych rozprawy doktorskiej. Badanie przeprowadzono w okresie od 16 marca do 12 kwietnia 2017 roku metodą ankiety internetowej (z wykorzystaniem kwestionariusza ankietowego umieszczonego na stronie internetowej) wśród 50 respondentów, w wieku od 31 do 45 lat (reprezentujących pracodawców z 50 małych i średnich przedsiębiorstw regionu kujawsko-pomorskiego), studentów 1 roku studiów podyplomowych kierunku „Kadry i Płace” Wydziału Zarządzania Uniwersytetu Technologiczno-Przyrodniczego im. J. i J. Śniadeckich w Bydgoszczy. Wśród osób reprezentujących pracodawców zdecydowanie dominowały kobiety (73\%). Prawie wszyscy $(93 \%)$ to osoby do 40 roku życia reprezentujący firmy średnie (80\%) i małe (pozostali).

$\mathrm{Z}$ uwagi na charakterystykę respondentów, wyników badania nie można traktować jako reprezentatywnego.

Celem badania była identyfikacja rodzajów i przykładów mediów społecznościowych oraz działań rekrutacyjnych $\mathrm{w}$ nich podejmowanych przez małe i średnie przedsiębiorstwa $\mathrm{z}$ województwa kujawsko-pomorskiego.

Media społecznościowe są stosunkowo nowym zagadnieniem na rynku polskim, jednak większość z badanych przedsiębiorstw (92\%) korzysta z nich z procesie rekrutacji. Najczęściej wykorzystują ich trzy rodzaje (wykres 1) - serwis społecznościowy biznesowy (82\%), serwis społecznościowy towarzyski (22\%), blog (12\%). Inne zidentyfikowane rodzaje mediów społecznościowych nie są wykorzystywane przez badane przedsiębiorstwa do rekrutacji pracowników. Wynika to ze specyfiki tych mediów. Serwis społecznościowy biznesowy i blog charakteryzują się możliwością nawiązania trwałych relacji zawodowych i wymianą wzajemnych doświadczeń. Użytkownicy mają możliwość umieszczania 
tam swoich CV, a także wymieniania się opinią na temat stanowisk zawodowych lub firm. Pozostałe media takie jak serwis video, serwis foto, wiki, serwis crowdsourcingowy czy zakupy grupowe służą przede wszystkim do celów marketingowych, sprzedażowych, rozrywkowych.

Wykres 1. Rodzaje mediów społecznościowych wykorzystywane w rekrutacji przez badane przedsiębiorstwa

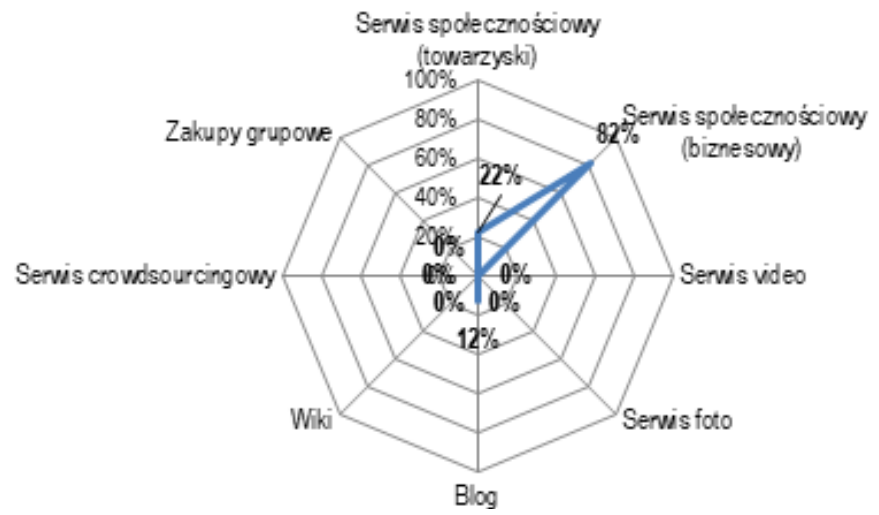

Źródło: Opracowanie własne na podstawie przeprowadzonego badania.

Wykres 2. Przykłady mediów społecznościowych wykorzystywane w rekrutacji przez badane przedsiębiorstw

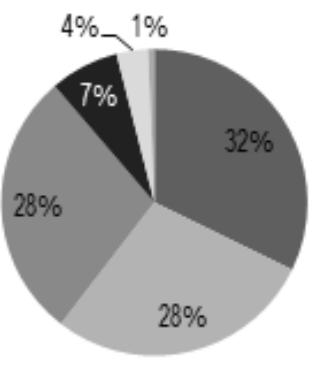

$$
\begin{aligned}
& \text { - Pracuj.pl } \\
& \text { - Linkedln } \\
& \text { - Golden Line } \\
& \text { - Facebook } \\
& \text { - Google + } \\
& \text { - Blog firmovy }
\end{aligned}
$$

Źródło: Opracowanie własne na podstawie przeprowadzonego badania.

Z kolei biorąc pod uwagę przykład mediów społecznościowych wykorzystywany w procesie rekrutacji (wykres 2) nieznaczna większość wykorzystuje w tym celu serwis Pracuj.pl (32\%), nieco mniej - LinkedIn (28\%) i Golden Line (28\%). Facebook został wskazany zaledwie przez $7 \%$ badanych przedsiębiorstw, Google+ przez 4\%, a blog firmowy jedynie przez $1 \%$. 
Wykres 3. Przykłady działań podejmowanych przez przedsiębiorstwa w mediach społecznościowych w rekrutacji pracowników

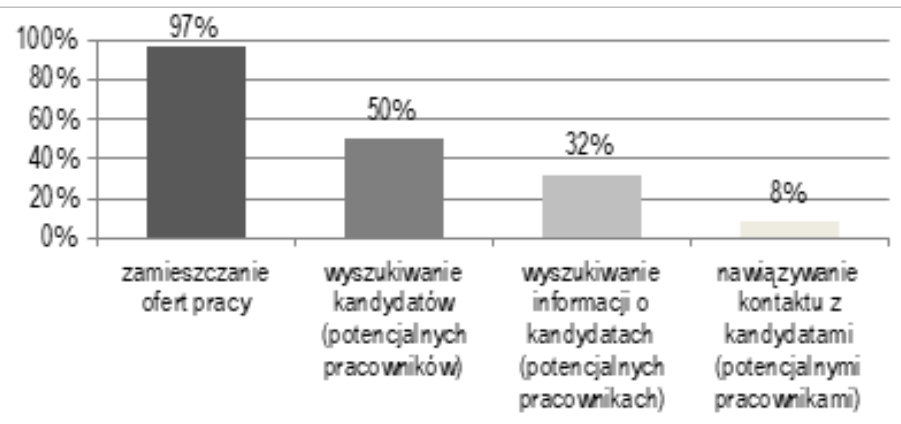

Źródło: Opracowanie własne na podstawie przeprowadzonego badania.

Analizie poddano również działania, jakie firmy podejmują w mediach społecznościowych w procesie rekrutacji (wykres 3). Zdecydowana większość, bo aż 97\% zamieszczania oferty pracy w mediach społecznościowych, 50\% wyszukuje kandydatów, 32\% wyszukuje informacji o kandydatach, a jedynie $8 \%$ nawiązuje z nimi kontakt. Wyniki badań dowodzą, że większość firm traktuje media społecznościowe jako nowe miejsce do zamieszczania ofert pracy, niewiele z nich skupia się na budowaniu relacji z potencjalnymi pracownikami.

\section{PODSUMOWANIE}

Współczesne przedsiębiorstwa funkcjonują w warunkach, w których rynek pracy staje się rynkiem pracobiorcy, a nie pracodawcy. Malejący wskaźnik bezrobocia skutkuje tym, że firmy mają problem ze znalezieniem odpowiednich pracowników, a ciągły rozwój Internetu i nowych technologii wymusza otwarcie się na nowe sposoby komunikacji. Coraz więcej polskich firm w procesie rekrutacji wykorzystuje nieszablonowe i niestandardowe narzędzia, jakimi są media społecznościowe. Zamieszczenie ofert pracy w tych mediach jednak nie wystarczy. Dziś to firma musi zabiegać o wartościowego pracownika, a nie odwrotnie. Firmy muszą być świadome, że w mediach społecznościowych, szczególnie tych o charakterze biznesowym uczestniczą eksperci w danej dziedzinie, których wiedzę i umiejętności łatwiej zweryfikować na podstawie rozmowy niż zamieszczonego CV.

\section{LITERATURA}

Dejnaka A. (2012), Nowe obszary zarzadzania zasobami ludzkimi. Pracownik i pracodawca w przestrzeni wirtualnej, „Zeszyty Naukowe Wyższej Szkoły Bankowej we Wrocławiu”, nr 30 . 
Drab-Kurowska A. (2012), Social media marketing w marketingu XXI wieku, [w:] G. Rosa, A. Smalec (red.), Marketing przyszłości. Trendy. Strategie. Instrumenty. Komunikacja marketingowa podmiotów rynkowych, „Zeszyty Naukowe”, nr 72, Problemy Zarządzania, Finansów i Marketingu, Uniwersytet Szczeciński, Szczecin.

Escher I., Petrykowska J. (2015), Aktywność polskich internautów w mediach społecznościowych, „Marketing i Rynek”, Nr 8.

Gogołek W. (2010), Komunikacja sieciowa.. Uwarunkowania, kategorie, paradoksy, Oficyna Wydawnicza ASPRA-JR, Warszawa.

Huijboom N., Broek van den T., Frissen V., Kool L., Kotterink B., Nielsen M. M., Millard J. (2009), Public Services 2.0: The Impact of Social Computing on Public Services, European Commission, Joint Research Centre, Institute for Prospective Technological Studies.

Igoe J.M. (2008), Social Networking Sites as Employment Tools, Geroge Mason University.

Jakrzewski, R. (2006), Jak rekrutować pracowników przez Internet, Wydawnictwo ODDK, Gdańsk

Kaplan A., Haenlein M., (2010), Users of the world, unite! The challenges and opportunities of Social Media. Business Horizons, Vol. 53, Issue 1.

Kaznowski D. (2010a), Podziat i klasyfikacja mediów społecznych, www.networkeddigital.com (15.01.2017).

Kaznowski D. (2010b), Media społeczne czy społecznościowe? That is the question, www.networkeddigital.com (15.01.2017).

Król H., Ludwiczyński A. (red.), (2006), Zarządzanie zasobami ludzkimi. Tworzenie kapitału ludzkiego organizacji, Wydawnictwo Naukowe PWN, Warszawa.

Listwan, T. (red.), (2010), Zarządzanie kadrami, wyd. 4 zm., C.H. Beck, Warszawa.

Mazurek G., (2012), Znaczenie wirtualizacji marketingu w sieciowym kreowaniu wartości, Poltext, Warszawa.

Miotk, A. (2013), Skuteczne social media. Prowadź działania, osiagaj zamierzone efekty, Helion, Gliwice

Mount M., Martinez M.G. (2014), A Tool for Open Innovation, California Management Review 2014, Vol. 56, Issue 4.

Nalazek U., Bonarowski M. (1999), Dystans do sieci, Businessman Magazine, nr 9.

\title{
RECRUITMENT ACTIVITIES COMPANY IN SOCIAL MEDIA ON THE EXAMPLE OF SME ENTERPRISES FROM THE KUJAWSKO-PO- MORSKIE
}

\begin{abstract}
Social media recently play an increasingly important role in the marketing and recruitment activities of many companies. They allow access not only to the desired group of customers, but also to potential employees. This allows the transfer of some recruitment activities to the social media, which the company has previously performed in the structures of its own organization, hence the purpose of the article was to identify types and examples of social media and recruitment activities undertaken by small and medium enterprises from the Kujawsko-Pomorskie.
\end{abstract}

Keywords: social media, recruitment of employees 
